\title{
Rosamund Snow
}

Researcher and campaigner for patients' involvement in healthcare

\section{David Payne}

London

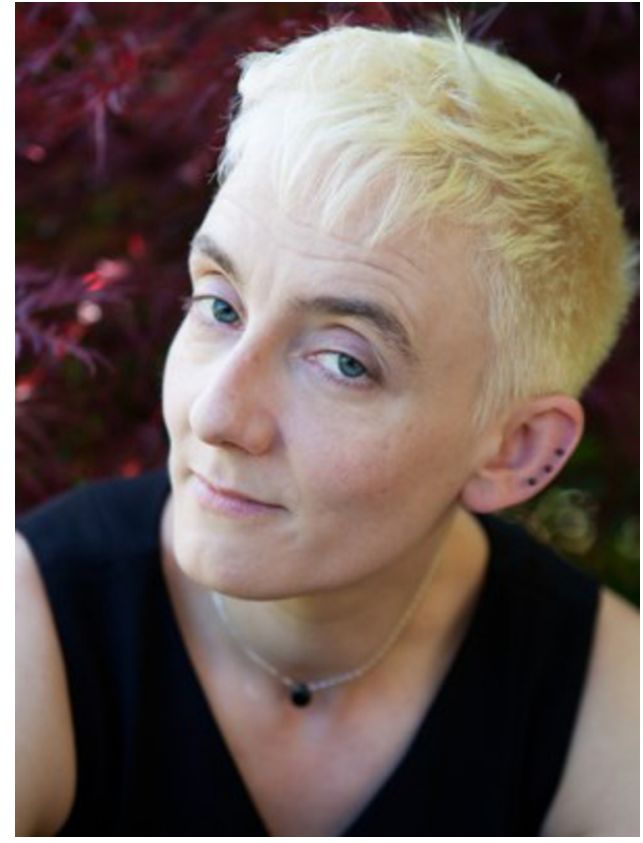

On her first day as The BMJ's patient editor in 2014, Rosamund Snow disclosed that a favourite pastime of hers was watching classic episodes of Coronation Street. Early storylines in the long running ITV soap were a particular draw, she said, especially rows between Ena Sharples, the street's self-appointed moral guardian, and Elsie Tanner, the middle aged single mother looking for the elusive Mr Right. Snow admired Elsie's spirited struggles to gain understanding and respect, and her resilience in the face of censorious neighbours who lazily stereotyped her.

\section{Placing patients centre stage}

It is tempting to speculate that she may have drawn parallels between Elsie's battle for recognition and a similar one waged by patients. Like Elsie they are often misunderstood, marginalised, and excluded from conversations. Snow fought to place patients centre stage in debates about service quality improvement and medical education.
Hers was a truly portfolio career, which at the time of her death at the age of 46 straddled The BMJ, an academic research post at Oxford University's Nuffield Department of Primary Care Health Sciences, and a collaboration with DeepMind, Google's artificial intelligence research venture, where she advised on its patient and public involvement strategy.

Diagnosed with type 1 diabetes as a teenager, one of Snow's first forays into service user research was in 2008, when a consultant at her outpatient clinic in Oxford asked if she would help to investigate its $15.7 \%$ DNA (did not attend) rate.

Her audit showed that in $61 \%$ of cases patients had either not been told of the appointment (often because a change of address had not been recorded) or they had spent up to 20 minutes trying to get through by telephone, often without success.

Describing herself as a "critical friend of the NHS" when she addressed a TED×NHS event in 2016 (https://player.vimeo. com/video/196716531), she urged her audience to involve patients in service quality improvement, saying: "All you have to do is ask us. And we can turn your bag full of question marks into a lightbulb moment."

\section{"Lightbulb" moment}

Snow's "lightbulb" career moment was in 2009, when her partner, Stephen Barton (the two had met while working at the Royal Society of Medicine), noticed a newspaper advertisement for paid $\mathrm{PhD}$ programmes at King's College London. At the time she was part of Transport for London's research team, investigating the information needs of the capital's 22500 bus drivers.

She secured funding for both a masters degree in research and a $\mathrm{PhD}$, which she gained in 2013 (her thesis was entitled The role of patient expertise inside and outside the health system: patient education in diabetes).

In her role at Oxford, she helped to develop patient involvement in curriculum design and taught communication skills to medical students, working alongside GP principal Helen Salisbury.

Salisbury says: "Rosamund was intensely curious and keen to sort problems out from the ground level up. She was full of ideas, and so challenging. She really made you see things in a 
different light and had this way of questioning systems when she felt they weren't working.

"For example, she was testing the hospital feedback systems. There was a suggestion box on the ward. She posted some ideas with her contact details, but heard nothing." Instead Snow turned to Twitter, posting updates about the hospital's failure to respond. ${ }^{1}$

Despite being an Oxford academic, Snow was decidedly "town," not "gown," with spiky bleached hair and a penchant for wearing high heels. An only child, she grew up in the Oxfordshire village of Finstock, where she learned the trombone, acting and performing at local venues with her musical mother, Mary, a psychiatrist.

After graduating with a politics degree from Sheffield University in 1993 and completing a postgraduate diploma in publishing at Oxford Brookes University, she settled in east Oxford, taking a keen interest in its vibrant local community and history.

The BMJ provided a return to academic publishing (her first job was at Blackwell). At the journal she assertively challenged internal systems and processes if she felt they weren't helpful to patients, and actively championed The BMJ's patient partnership strategy (www.bmj.com/campaign/patientpartnership). With a skilled mix of advocacy, innovation, and good humoured support she worked tirelessly alongside fellow editors and authors to help them understand what patient involvement really means and how to advance it in both research and medical education, by involving patients as peer reviewers of research articles and co-authors of education articles. She also spearheaded a move to include patients on the judging panel for the annual BMJ Awards and advocated for other journals to take up the "patients included" baton.
In January 2015 she launched a new article type, "What your patient is thinking." Unlike "Patient journeys," which they replaced, WYPITs (as they have come to be known) were not co-authored articles and did not include a clinician's perspective. Instead they are "owned, led, and edited by patients," with titles such as "Before I kick the bucket, I want to say thank you," "Why there's no point telling me to lose weight," "Never say never about our child," and "Excuse me, doctor: I can still hear you." ${ }^{-5}$

Paul Buchanan, a member of The BMJ's patient panel, said: "As an academic, Rosamund was a true ethnographer with a rare ability to listen without having prejudged anything."

Fellow panel member Anya de Iongh adds: "I was utterly terrified by Rosamund when I first met her. She was influencing medical institutions from a patient's perspective. She was really intimidating, but in the best possible way."

Snow leaves Stephen; her parents, Mary and Gordon; two stepdaughters; and three step grandchildren.

\section{Biography}

Rosamund Snow (b 1971; PhD, MReS), died by suicide on 2 February 2017

BMJ Patient Editor. 2017. twitter.com/BMJPatientEd/status/821338360740450304.

2 Townsend JD. Before I kick the bucket, I want to say thank you. BMJ 2015;346:h4706. doi:10.1136/bmj.h4706 pmid:26467035.

3 Lewis E. Why there's no point telling me to lose weight. BMJ 2015;346:g6845. doi:10. 1136/bmj.g6845 pmid:25603805.

4 Pearson A. Never say never about our child. BMJ 2015;346:h1246. doi:10.1136/bmj. h1246 pmid:25947174

5 Klein M. Excuse me, doctor: I can still hear you. BMJ 2015;346:h2647. doi:10.1136/bmj. h2647 pmid:26085079.

Published by the BMJ Publishing Group Limited. For permission to use (where not already granted under a licence) please go to http://group.bmj.com/group/rights-licensing/ permissions 